\title{
EFFECT OF TEACHERS' ABILITIES ON STUDENTS' MOTIVATION WITH VARYING LEVELS OF INTELLECTUAL ABILITIES IN THE ECONOMICS
}

Kateřina Berková ${ }^{\square}$, Kristýna Krejčová ${ }^{2}$

\author{
${ }^{1 \bowtie}$ Department of Economic Teaching, Faculty of Finance and Accounting Methodology, University of Economics, Prague, nám. W. Churchilla 4, \\ Prague, 130 67, Czech Republic, +420 224095 134, katerina.berkova@vse.cz \\ ${ }^{2}$ Department of Economic Teaching Methodology, Faculty of Finance and Accounting, University of Economics, Prague, Czech Republic
}

Highlights
- The above-average intelligent students are motivated by expertise and exposition of curriculum
- The average intelligent students are motivated by expertise, abilities to develop thinking
- The average intelligent students are motivated above that by exposition of curriculum

\section{Abstract}

Intelligence and motivation are two crucial components of the education process that can significantly influence its efficiency. The level of intelligence determines our ability to learn from experience and to solve a problem successfully, whereas motivational processes energize and organize our behavior to reach our goals. This paper is connected to our previous article focused on the influence of teachers' abilities on secondary business schools' students' motivation in the Economics.

In our current study, we monitored the motivational potential of teachers' abilities in a connection with students' level of intelligence, measured by Vienna Matrices Test. As we would expect according to the results of our previous study, the expertise of teachers has the most important influence in the groups of both the above-average intelligent and the average intelligent students. Nevertheless, we found some differences in other preferences of both groups: except the teachers' expertise, the average intelligent students refer to be motivated mostly by exposition of curriculum and ability to develop thinking, whereas above-average students refer only about the exposition of curriculum (except the teachers' expertise). The next factor that we observed in our study is an amount of time that students spend on preparation to school.

\section{Keywords}

Economic education, educational methods, motivation, intellectual abilities, secondary business school, teacher's abilities

Berková K., Krejčová K. (2016) “Effect of Teachers’ Abilities on Students’ Motivation with Varying Levels of Intellectual Abilities in the Economics", Journal on Efficiency and Responsibility in Education and Science, Vol. 9, No. 3, pp. 81-87, online ISSN 18031617, printed ISSN 2336-2375, doi: 10.7160/eriesj.2016.090304.

\section{Introduction}

Motivation can be defined as a sum of strengths that energize and organize behavior and experiencing of an individual with a goal to change current unsatisfied situation or to reach something positive (Plháková, 2003: 319). In the field of education, motivation can be described as one of the crucial influences that determines effectivity and fruitfulness of educational process. No learning at school occurs without motivation (Fontana, 2014: 153). Despite many educational systems use various forms of external motivational incentives a student can gradually improve his/her ability to motivate himself /herself without dependence on external sources of motivation (Č́a and Mareš, 2001: 506). According to the self-determination theory, external motivation can be modified into intrinsic motivation under certain circumstances, particularly if the task corresponds with values and beliefs of an individual and helps to fulfil his/ her psychological needs (Tohidi and Jabbari, 2012: 820).

Some issues of motivation in education process can be related to the issues of work motivation, because children observe and learn the interests, values and attitudes towards responsibilities of their parents. Kolman, Chýlová and Selby (2012) try to systematize current theories of work motivation. According to their research in the Czech Republic, the older, less educated respondents from the country margins understand job performance differently in comparison with younger, more educated inhabitants who live in the central part of the country. 'These two kinds of respondents differ mainly in their experience on the job. The younger ones believe that to produce on a job will bring rewards to them. The others do not believe it is so' (Kolman, Chýlová and Selby, 2012: 96). These attitudes can influence motivation of children and students in the Czech Republic.

Motivation in education process is also age-specific and can significantly change during the school attendance. Vostrá Vydrová, Jindrová and Dömeová (2012) analyze motivation of distance students. They observe higher motivation of adult students. Often they need to reach university degree to keep or improve their work position. Successful termination of their studies can also be more important for their private social status. These factors lead to more intensive self-study and higher responsibility in comparison with regular students (Vostrá Vydrová, Jindrová and Dömeová, 2012: 40).

Ferreira, Cardosob and Abrantesc (2011) investigate interaction between a negative sense of school belonging and intrinsic motivation and their impact on perceived learning. With the sample of 1986 high school student, they proved that a negative sense of school belonging negatively affects intrinsic motivation and also perceived learning. The authors conclude that higher intrinsic motivation leads to more positive self-view in learning and to more positive attitude towards their field of study (Ferreira, Cardosob, and Abrantesc, 2011: 1712-1713). Similar findings can be found in study of Popa (2015) that analyzes impact of motivational factors (self-efficacy, locus of control and interest in subject) and regulated learning's influence on 
the level of school performance at middle school students. According to their results, 'academic performance increases if the person aware of his purpose, controls, regulates and directs his impulses, follows the rules, prefers careful planning and demonstrates perseverance in achieving success' (Popa, 2015: 2552).

In this article, we related our results of previous study (Krejčová and Berková, 2016) to the factor of intelligence, because it reflects a general level of abilities that could significantly influence the efficiency of a learning process. Despite we measured only the level of nonverbal intelligence in our research, we come out from the definition of intelligence by Sternberg (2005: 189), who formulated the successful intelligence on the basis of four crucial characteristics: '1) the ability to achieve one's goals in life, given one's sociocultural context; 2) by capitalizing on strengths and correcting or compensating for weaknesses; 3) in order to adapt to, shape, and select environments; and, 4) through a combination of analytical, creative, and practical abilities'.

In a relationship between intelligence and motivation it is important to realize that it is above all the self-perceived level of individual's intelligence, also known as the self-concept of intelligence. In the study of Gerstenberg et al. (2014), the selfconcept of intelligence was significant predictor for the level of achievement motivation. The authors further confirmed that by modest individuals, the relation between self-concept of intelligence and real performance on the test of intelligence is mediated by the level of achievement motivation.

Apart from the self-concept of the intelligence, also teacher's individual option about the nature of intelligence could be crucial in the education process (if a teacher beliefs that the cognitive processes are modifiable or if he/she is persuaded about innate level of intelligence etc.). Jonsson and Beach (2012: 387) define the implicit theory of intelligence as 'the more or less systematic ways people think about the ability to learn'. This persuasion can significantly affect the choice of teaching methods that teacher uses in the education and the general approach to improving of his/her students' abilities.

Motivation of a student is significantly determined by personality of a teacher. Teacher's quality affects his/her personality characteristics - qualification level, scope, form and quality of teacher's training, specialization, age, professional experience, ethnicity, verbal skills and attitudes (Windham, 1988). The ideal teacher disposes resilience, adaptability, the ability to absorb new knowledge, social empathy and communication skills (Dytrtová and Krhutová, 2009: 15). The main determinant of the educational process is the teacher's personality and using of teaching methods. Appropriate use of teaching methods causes a positive effect on teaching.

Students with lack of motivation or demotivated ones are not interested in the process of solving problems, but they are only interested in the result (Boekaerts, 2004). The most important stimulus for motivation is experiencing successes and failures (Elliot, 1999). Study success is related to the used teaching methods. As evident from the several empirical researches, in teaching economic subjects traditional teaching methods are still dominating being supplemented by problem-solving teaching methods. This finding was confirmed by Králová (2009) who conducted a research in 2003 and focusing on 200 students of business schools in the Czech Republic. It was proved that in teaching of Economics verbal reproduction prevails. The least represented activating methods were discussions, economic games, staging methods and independent students' work. The new research proves that there is a causal link between the length of teaching experience and applied teaching methods. The longer experience a teacher has the less sophisticated activating methods supporting economic thinking are used. A change occurs by teachers with teaching experience of less than 10 years (Berková and Králová, 2015: 42).

Active learning is closely connected with the development of thinking. In the economic education, the development of economic thinking is very important. This trend results from the need to support financial literacy. For the development of economic thinking is needful to use higher levels of Bloom's taxonomy (i.e. application, analysis, synthesis, evaluation and creating). Authors Tetteh and Sarpong (2015) examined levels of Bloom's taxonomy. They found based on empirical research that active learning impacts on study results and motivation of students. Activity can be achieved by students' creativity, which is the highest level of Bloom's taxonomy. In this context, we can already talk about the development of economic thinking. Based on the research of Zoller (2015: 4476), the guiding conceptual model of Higher-Order Cognitive Skills has been developed. Implementation of this model requires to use the teaching methodology of case studies and to emphasize the activity in the educational process.

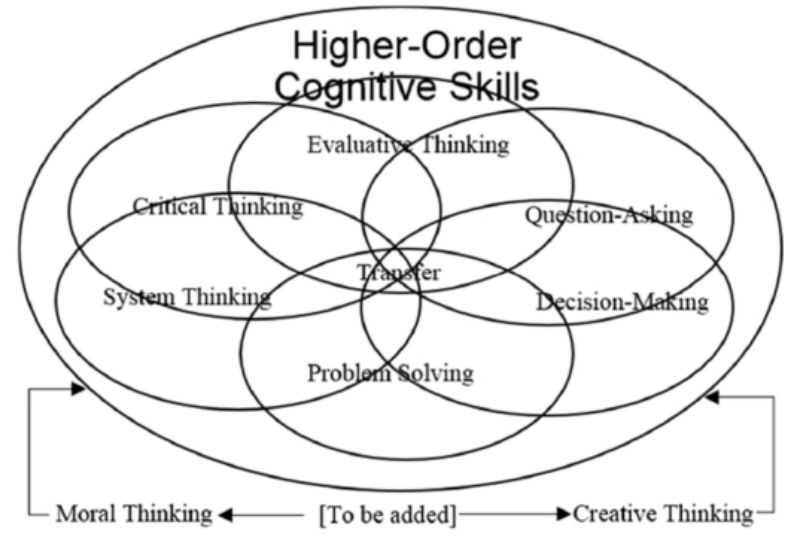

Figure 1: The guiding conceptual model of Higher-Order Cognitive Skills (source: Zoller, 2015: 4476)

The model shows the gnoseological processes with effect on the thinking that may have significant positive impact on students' motivation to study of the subject. It is necessary to demonstrate the curriculum on specific examples from practice with using of problem solving. This is also consistent with the trends of economic education - entrepreneurship (see Aff and Fortmüller, 2013).

The objective of our article is to analyze motivational influence of a teacher on students with varying levels of intellectual abilities from the second and third years at secondary business schools in the Economics. The subject of the research is to quantify the impact of teachers' skills - communication and presentation skills, exposition of curriculum, ability of developing thinking and expertise of teachers - on the students' motivation with varying levels of intellectual abilities. The results will help to implement innovative methodology in the training of teacher trainees of economic subjects at secondary schools to achieve more effectively the educational goals of students at different intellectual levels. Our study expands first research oriented the assessment of effect of teachers' abilities on students' motivation 
without reference to levels of intellectual abilities (Krejčová and Berková, 2016).

Following hypotheses are subjected to empirical verification:

The null hypothesis $\left(\mathrm{H}_{0-1}\right)$ : Monitored skills of teachers do not influence motivation of the above average intelligent students in the Economics.

An alternative hypothesis $\left(\mathrm{H}_{1-1}\right)$ : Motivation of the above average intelligent students in the Economics is influenced by at least one of the teachers' examined skills.

The null hypothesis $\left(\mathrm{H}_{0-2}\right)$ : Monitored skills of teachers do not influence motivation of the average intelligent students in the Economics.

An alternative hypothesis $\left(\mathrm{H}_{1-2}\right)$ : Motivation of the average intelligent students in the Economics is influenced by at least one of the teachers' examined skills.

\section{Materials and Methods}

The research was conducted in 2015 at 3 business schools in the Czech Republic that are participated in the research project. There are two Business Academies from Prague and one Business Academy from Vysočina region (Jihlava). These schools were chosen by reason of the realization of the same field of study - Business Academy and their different methods that support students' economic thinking in the economic subjects. Development of economic thinking is main sphere of the authors' survey. The difference between these schools helped to get the relevant sample based on the deliberate choice. The survey involved 368 students from the second and third years of studies at secondary business schools out of which 277 students were used for the data analysis (Table 1). The research involved 221 girls (79.8\%) and 56 boys (20.2\%) between 16 and 18 years of age. Although the questionnaires and tests were distributed to 368 respondents, the authors obtained data only from 277 respondents

\begin{tabular}{|c|c|c|c|c|c|c|}
\hline \multirow{2}{*}{ Parameters } & \multicolumn{2}{|c|}{ 2nd year } & \multicolumn{2}{c|}{ 3rd year } & \multicolumn{2}{c|}{ Total } \\
\cline { 2 - 7 } & Absol. & Relat. & Absol. & Relat. & Absol. & Relat. \\
\hline Premise & 170 & $\mathrm{x}$ & 198 & $\mathrm{x}$ & 368 & $\mathrm{x}$ \\
\hline Return & 124 & $72.9 \%$ & 153 & $77.3 \%$ & 277 & $75.3 \%$ \\
\hline
\end{tabular}

Table 1: Research Sample, 2015 (source: own calculation)

Students from the first and fourth years were not included because the economic education in these years is less didactically appropriate for the development of economic thinking. In the first year of the business academy, the subject Accounting is missing. In the fourth year, the education in Economics is too advanced for development of basis of economic thinking. Students are monitored in intellectual level. In summary, for both study years is assessed the level of abstract-visual thinking of the students:

- 138 individuals (49.8\%) above average intelligence and highly exceptional intelligent (intellectual level above 110),

- 109 individuals (39.4\%) of average intelligence (intellectual level ranging from 91 to 109),

- 30 individuals (10.8\%) below average and significantly below the average intelligence (intellectual level below 75).
Because of the very low number of average and significantly below the average intelligent individuals $(n=30)$ this group is not further analyzed. The sample is too small to be able to identify motivation ways towards this group of students. In addition, we assume reduced validity of the results by this group of students due to the lack of motivation of some individuals. Therefore, the analysis focuses on the first two groups of students (138 and 109 individuals).

For data collection, the method of questioning technique and diagnosing intelligence were used. The validity of the questionnaire assessing the competence of teachers had been detected by testing in a pilot study on a small sample. Students filled questionnaires to find their attitudes to evaluate the personality of the teacher of Economics in the context motivation in the Economics.

To assess the general level of intelligence of our respondents, we used Vienna Matrices Test, the one-dimensional test of abstract-visual thinking. The validity of the test to measure the intellectual level of students was consulted with the Testcentre in the Czech Republic, which deals with the psychological diagnosis and guarantees the selection of appropriate test. The choice of this type of diagnostic instrument also corresponds with our theoretical assumptions that are described in the introduction of this article. The test allows the quantification of the overall level of the intellective performance in the area of intellectual-abstract visual thinking. The processing of the test is a maximum of 25 minutes. "The test consists of 24 items that are ordered with increasing difficulty. Each task includes a matrix of $3 \times 3$ images with a missing figure in the third row. The task is to complete the matrix by selecting one of the eight offered solutions. The principle of solution is the discovery of rules that defines the relationship between the images in each row or column. Creating a rule is based on detection of mutual relations between the elements and finding relevant solution. The overall strategy applies perception, thinking, attention, shortterm memory" (Forman, 2002: 8). Despite the test also exists in a computer adaptive testing form that is largely comparable to the paper-pencil form (Žitný and Halama, 2012), the paper version was chosen as it was more suitable to our experiment.

Students filled questionnaires to find their attitudes to evaluate the motivational potential (i.e. analytic approach to evaluate personality of the teacher). Students assigned points 1-5 to each teacher's ability (the higher the point value, the better the teacher's ability to motivate students to the subject). It was also possible to assign zero (i.e. student cannot assess the monitored ability). Teacher's personality evaluation was monitored in five categories, each containing files describing the ability of teachers (Table 2).

In addition, we monitored students' weekly preparation time, which was identified by codes on a scale 1-5, which are represented by these time intervals - I am not preparing for the subject at all; less than 60 minutes, 1-2 hours, 2-4 hours, more than 4 hours. 
Berková K., Krejčová K. - ERIES Journal vol. 9 no. 3

\begin{tabular}{|c|c|c|}
\hline Category & $\begin{array}{c}\text { Number of } \\
\text { Abilities in } \\
\text { Category }\end{array}$ & Abilities in Category \\
\hline $\begin{array}{c}\text { Communication } \\
\text { Skills }\end{array}$ & 6 & $\begin{array}{c}\text { pronunciation, interest, } \\
\text { pace and melody, keeping } \\
\text { attention, paying attention, } \\
\text { listening }\end{array}$ \\
\hline $\begin{array}{c}\text { Presentation } \\
\text { Skills }\end{array}$ & 4 & $\begin{array}{c}\text { examples of real life } \\
\text { situations, good actor, eye } \\
\text { contact, dealing with stage } \\
\text { fright }\end{array}$ \\
\hline $\begin{array}{c}\text { Exposition of } \\
\text { Curriculum }\end{array}$ & 3 & $\begin{array}{c}\text { practical meaning of the } \\
\text { curriculum, adopting } \\
\text { unconventional ideas, } \\
\text { explanations of mistakes }\end{array}$ \\
\hline $\begin{array}{c}\text { Ability of } \\
\text { Developing } \\
\text { Thinking }\end{array}$ & 2 & $\begin{array}{c}\text { interest in developing } \\
\text { a task, leading to thinking }\end{array}$ \\
\hline Expertise & 1 & $\begin{array}{c}\text { answer factually correct and } \\
\text { consistently to all questions }\end{array}$ \\
\hline
\end{tabular}

Table 2: Description of Categories and Files of Examined Abilities, 2015 (source: authors)

Data were processed and analyzed with the support of NCSS statistical program (version 2007). Verification of null hypothesis was performed based on non-parametric Kruskal-Wallis test at $5 \%$ significance. Data were analyzed based on the method OneWay Analysis of Variance that compares mean value of files. The Kruskal-Wallis test is the alternative of method One-Way Analysis of Variance and this may be used if the data have not normal distribution. The importance of differences between the monitored skills is evaluated via paired comparison test (modification Tukey's multiple comparison method). This test may be used if the data is not normal distribution. Normality of our analyzed data has not been proven. Using Tukey-Kramer Multiple-Comparison test is one of the methods of One-Way Analysis of Variance and identifies the conclusive differences between the surveyed factors. These differences are analyzed for the first two groups of students - the above average and the average intelligent students. Tukey-Kramer MultipleComparison test proved effect of the combination of more abilities on students' motivation in the Economics. For analysis of date is used mean of assigned points to each teacher's abilities in relative form.

\section{Results}

\section{Verification of $\mathrm{H}_{0-1}$ - motivation of the above average} intelligent students

Null hypothesis $\mathrm{H}_{0-1}$ is rejected at the $5 \%$ level of significance ( $\mathrm{P}$ $<0.01)$. The influence of at least one of the teachers' surveyed ability to motivate 138 of the above average intelligent student is conclusive (Table 3 ).

\begin{tabular}{|c|c|c|c|}
\hline DF & Chi-Squaer & $\begin{array}{c}\text { Prob Level } \\
(\mathbf{P})\end{array}$ & $\begin{array}{c}\text { Decision } \\
(\mathbf{0 . 0 5})\end{array}$ \\
\hline 4 & 44.154 & 0.000 & ${\text { Reject } \mathrm{H}_{0}}$ \\
\hline
\end{tabular}

Table 3: Proven dependence - Kruskal-Wallis test, 2015 (source: authors)

The importance of differences between the monitored skills is proved by Tukey-Kramer Multiple-Comparison test (Table 4).

\begin{tabular}{|c|c|c|}
\hline Monitored Skill & Mean & Differences between skills \\
\hline $\begin{array}{c}\text { Communication } \\
\text { Skill }\end{array}$ & 0.722 & Expertise \\
\hline Presentation Skill & 0.743 & Expertise \\
\hline $\begin{array}{c}\text { Ability of } \\
\text { Developing } \\
\text { Thinking }\end{array}$ & 0.768 & Expertise \\
\hline $\begin{array}{c}\text { Exposition of } \\
\text { Curriculum }\end{array}$ & 0.781 & $\begin{array}{c}\text { Communication Skill, } \\
\text { Presentation Skill, Ability of } \\
\text { Developing Thinking }\end{array}$ \\
\hline Expertise & 0.838 \\
\hline
\end{tabular}

Table 4: Tukey-Kramer Multiple-Comparison test - analysis of differences, 2015 (source: authors)

Differences between skills are graphically depicted in a box diagram via exploratory analyzes (Figure 2).

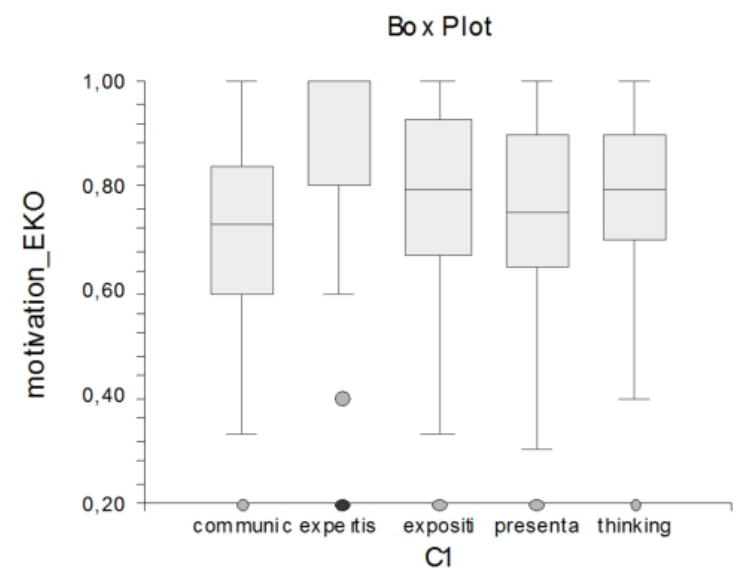

Figure 2: Exploratory Analysis of Differences - the above average intelligent students, 2015 (source: authors)

In our research focused on 138 of the above average intelligent students from the second and third years of studies at secondary business schools, paired comparison proved that in the Economics students are most motivated by teachers' expertise.

This ability is significantly different from other monitored teachers' skills - communication and presentation skills, ability of developing thinking. The ability of exposition of curriculum is not significantly different from other monitored skills. The above average intelligent students perceive higher motivational potential in the ability of exposition of curriculum, compared with communication and presentation skills and ability of developing thinking. Empirically, it has been proven that expertise of teachers and their ability of exposition of curriculum represent almost the same motivational potential for above average intelligent students.

Based on Tukey-Kramer Multiple-Comparison test, effect of combination of the monitored abilities on motivation of 138 above average intelligent students was analyzed. It was proven that teachers do not support motivation of this student group of subject Economics via further action and improvement of their communication and presentation abilities and ability of developing thinking. The most important fact is that there is expertise and ability of exposition of curriculum.

In terms of the relationship of intellectual abilities and weekly preparation time, it has been proven that above average intelligent students are preparing on the subject Economics in shorter time 
(less than 60 minutes, the maximum is 2 hours) or they are not preparing for the subject at all (Table 5). This result is consistent with level of intellectual abilities of these students. Preparation time of the above average intelligent students (11.5\%) over a longer period of time (more then 2 hours), for example, can be explained by their greater interest in the Economics.

\begin{tabular}{|c|c|c|c|c|}
\hline $\begin{array}{c}\text { I am not } \\
\text { preparing for the } \\
\text { subject at all }\end{array}$ & $\begin{array}{c}\text { Less than 60 } \\
\text { minutes }\end{array}$ & $\begin{array}{c}1-2 \\
\text { hours }\end{array}$ & $\begin{array}{c}2-4 \\
\text { hours }\end{array}$ & $\begin{array}{c}\text { More than 4 } \\
\text { hours }\end{array}$ \\
\hline $22.5 \%$ & $37 \%$ & $29 \%$ & $7.2 \%$ & $4.3 \%$ \\
\hline
\end{tabular}

Table 5: Weekly preparation time of the above average intelligent students, 2015 (source: authors)

Attitudes of the above average intelligent students to personality of teacher of subject Economics were compared in terms of aspect of quality and motivational potential of monitored abilities (Figure 3). Evaluation quality of monitored abilities is not the objective of our article, but it is the subject of our research project. Method for evaluation quality of teacher's personality is the same as evaluation of motivational potential of abilities (see Pasiar, Berková et al., 2015). It results from comparison that the teachers do not develop enough their abilities needed for students' motivation in the Economics. All monitored abilities would more motivate students in the Economics. The students must actually experience the abilities of teachers or the teachers must more develop their abilities (Figure 3).

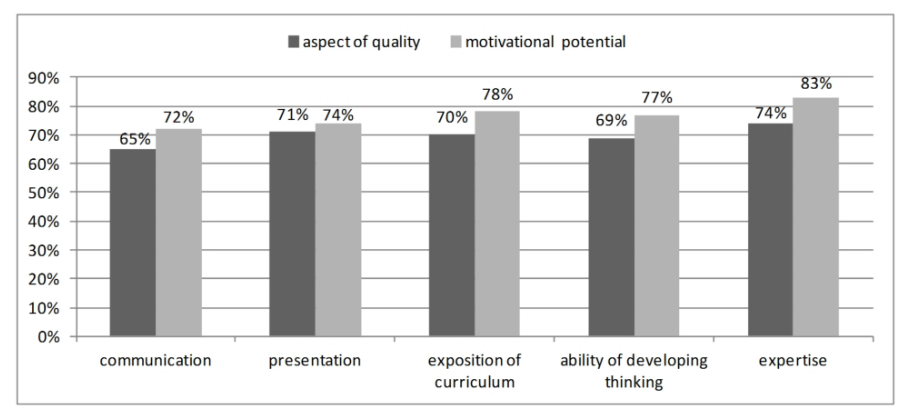

Figure 3: Comparison of quality and motivational potential of teachers' abilities, 2015 (source: own calculation)

Verification of $\mathrm{H}_{0-2}$ - motivation of average intelligent students

Null hypothesis $\mathrm{H}_{0-2}$ is rejected at the $5 \%$ level of significance $(\mathrm{P}<0.01)$. The influence of at least one of the teachers' surveyed ability to motivate 109 of average intelligent student is conclusive (Table 6).

\begin{tabular}{|c|c|c|c|}
\hline DF & Chi-Squaer & Prob Level (P) & Decision (0.05) \\
\hline 4 & 32.669 & 0.001 & Reject $\mathrm{H}_{0}$ \\
\hline
\end{tabular}

Tab. 6: Proven dependence - Kruskal-Wallis test, 2015 (source: authors)

The importance of differences between the monitored skills is proved by Tukey-Kramer Multiple-Comparison test (Table 7).

\begin{tabular}{|c|c|c|}
\hline Monitored Skill & Mean & Differences between skills \\
\hline Communication Skill & 0.716 & Expertise \\
\hline Presentation Skill & 0.722 & Expertise \\
\hline $\begin{array}{c}\text { Exposition of } \\
\text { Curriculum }\end{array}$ & 0.775 & - \\
\hline $\begin{array}{c}\text { Ability of Developing } \\
\text { Thinking }\end{array}$ & 0.783 & - \\
\hline Expertise & 0.828 & $\begin{array}{c}\text { Communication Skill, } \\
\text { Presentation Skill }\end{array}$ \\
\hline
\end{tabular}

Table 7: Tukey-Kramer Multiple-Comparison test - analysis of differences, 2015 (source: authors)

Differences between skills are graphically depicted in a box diagram via exploratory analyzes (Figure 4).

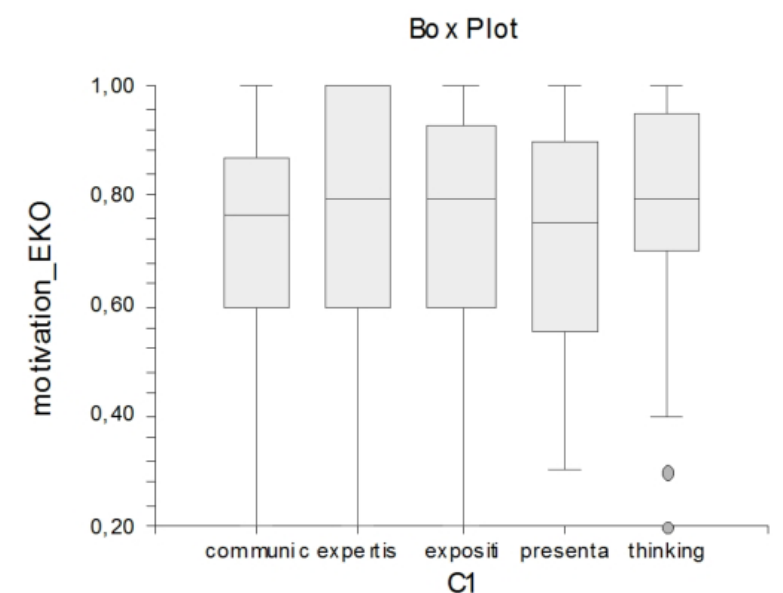

Figure 4: Exploratory Analysis of Differences - average intelligent students, 2015 (source: authors)

In our research focused on 109 of average intelligent students from the second and third years of studies at secondary business schools, paired comparison proved that in the Economics students are most motivated by teachers' expertise.

This ability is significantly different from other monitored teachers' skills - communication and presentation skills. The ability of exposition of curriculum and the ability of developing thinking are not significantly different from other monitored skills. The average intelligent students perceive higher motivational potential in the ability of exposition of curriculum and developing thinking, compared with communication and presentation skills. Empirically, it was proven, that expertise of teachers, their ability of exposition of curriculum and developing thinking represent almost the same motivational potential for average intelligent students.

Based on Tukey-Kramer Multiple-Comparison test, effect of combination of the monitored abilities on motivation of 109 average intelligent students was analyzed. It was proven that teachers do not support motivation of this student group of subject Economics via further action and improving their communication and presentation abilities. Last but not least, there is expertise, ability of exposition of curriculum and developing thinking.

In terms of the relationship of intellectual abilities and weekly preparation time, it has been proven that average intelligent students prepare on the subject Economics mostly 1-2 hours $(41.3 \%)$. It would be expected that these students will pay more attention to this subject, but the trend is opposite. Only, $16.5 \%$ of average intelligent students prepare 2-4 hours a week, which is adequate for their intellectual level (Table 8). It can be stated that the average intelligent students are not more interested in the preparation for the subject Economics than the above average intelligent students.

\begin{tabular}{|c|c|c|c|c|}
\hline $\begin{array}{c}\text { I am not preparing } \\
\text { for the subject at all }\end{array}$ & $\begin{array}{c}\text { Less than } \\
60 \text { minutes }\end{array}$ & $\begin{array}{c}1-2 \\
\text { hours }\end{array}$ & $\begin{array}{c}2-4 \\
\text { hours }\end{array}$ & $\begin{array}{c}\text { More than } \\
4 \text { hours }\end{array}$ \\
\hline $12.8 \%$ & $29.4 \%$ & $41.3 \%$ & $16.5 \%$ & $0 \%$ \\
\hline
\end{tabular}

Table 8: Weekly preparation time of average intelligent students, 2015 (source: authors) 
Attitudes of average intelligent students to personality of teacher of subject Economics were compared in terms of aspect of quality and motivational potential of monitored abilities (Figure 5). It results from comparison that the teachers do not develop enough their abilities needed for students' motivation in the Economics (as the above average intelligent students). All monitored abilities would more motivate students in the Economics. The students must actually experience the abilities of teachers or the teachers must more develop their abilities. The results are very consistent with the results in the group of the above average intelligent students. Yet, the average intelligent students only evaluate worse the quality of ability of exposition of curriculum than the above average intelligent students.

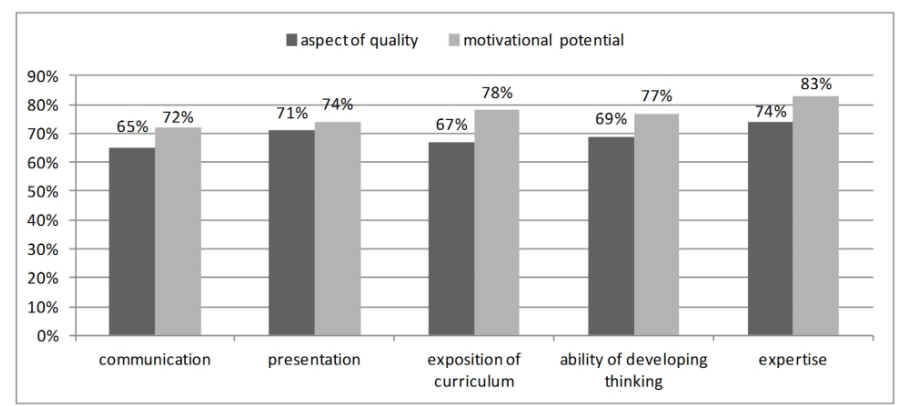

Figure 5: Comparison of quality and motivational potential of teachers' abilities, 2015 (source: own calculation)

\section{Discussion}

Results of our research proved that students' motivation in the Economics is most influenced by the teachers' expertise. According to the self-determination theory (Tohidi and Jabbari, 2012), this finding could support motivation of teachers to develop and enrich their expertise in their pre-gradual education and in life-long education as well, because they need their expertise not only to gain their master degree or certificate from a course, but above all to transmit knowledges and to support the intrinsic motivation of their students by means of their expertise.

From the critical point of view, the superiority of the teacher's expertise as the most important teachers' ability that influence the motivation of students in Economics could be seen as a consequence of overusing of traditional teaching methods at secondary business schools in the Czech Republic. When the students do not experience e. g. the development of thinking during his/her education, he/she cannot assess this teaching method as important for his/her motivation in the questionnaire despite the need to develop the thinking strategies in the education is evident (Krejčová, 2013).

Kolman, Chýlová and Selby (2012) suppose that structure of motivation is culture-specific. The preference of teachers' expertise in our study can be related to the ideology of motivation that Kolman, Chýlová and Selby (2012: 95) called the protestant ethic, in that the value is attached to hard work that is necessarily connected with acquisition of knowledges and expertise. In the context of research of Vostrá Vydrová, Jindrová and Dömeová (2012) that emphasize age-specific factors of motivation, we should consider relativity of our findings. By younger students, communication and presentation skills could be more important than expertise of a teacher; by older students, motivation could be more affected by ability to develop thinking. This hypothesis comes out of the mechanisms of cognitive development (Sternberg and Williams, 2010) and should by verified by subsequent research.
One of the most worthwhile findings of our study lies in the analysis of motivational needs of students with above-average level of intelligence in subject Economics. Lipovská and Fischer (2016) emphasize the need to develop above average high abilities in the education. They ascertained in their study of talented students in the Czech Republic that their respondents explain their success (with a possibility to assign more options) by their interest in the field (69\%), diligence (54\%) and paternal support (42\%). The result, which does not sound very supportive for the Czech educational system, shows that only $29 \%$ of respondents explain their success by support of their teachers. We suppose that our research helps to understand educational needs of above-average students at least in subject Economics. In light of teaching management and motivation of students, the work with the average intelligent students is more exacting for teachers. Our research proved that for this group of students, not only expertise and exposition of curriculum are important but also developing thinking. The interest of the average intelligent students in the Economics is lower. They underestimated homework. Therefore, it is necessary that the teachers work individually with these students and give them more attention. In terms of study skills of students, it is necessary to differentiate the complexity of tasks to fixation of curriculum. We recommend using practical examples for this group of students, with an emphasis on entrepreneurship (Aff and Fortmüller, 2013). The teachers can also use Bloom's taxonomy of cognitive objectives (Tetteh and Sarpong, 2015). Concept of these tasks should be adequate for this group of students, i.e. you can use still levels of application and analysis.

The subject Economics supports effective application of curriculum to practical situation. The solving of practical situations requires a high expertise of teachers. In this context, it is necessary to change teaching methods and to apply more problematic and activating methods in the teaching. These methods allow students to see progress, not only the finished result. Such methods are motivating (Boekaerts, 2004). The traditional teaching methods are still dominant (Králová, 2009; Berková and Králová, 2015). Those methods are not so motivating for students. In a group of the above-average intelligent students you can increase motivation for the subject Economics to use progressive teaching methods and gnoseological processes which illustrated the conceptual model of Higher-Order Cognitive Skills (Zoller, 2015: 4476). The teachers can also use higher levels of Bloom's taxonomy, i.e. application, analysis, synthesis, evaluation or creativity. These students are most motivated by expertise of teachers and its exposition of curriculum in the form of analysis and interpretation of errors in practical situations. It is more desirable to use activate methods that can support their interest in the Economics.

\section{Conclusion}

Motivation is one of the most important issues in education that can significantly support effectivity of educational process. Motivation of students has specific structure and is determined by age, culture, personality and other specific factors. Personality of a teacher significantly affects motivation of students.

Our study expands first research oriented at the assessment of effect of teachers' abilities on 277 students' motivation between 16 and 18 years of age with varying levels of intellectual abilities. The students were differentiated into two groups - the aboveaverage intelligent and the average intelligent. Both groups were motivated by expertise of teacher and his explanation of 
the curriculum with an emphasis on practical meaning of the curriculum, adopting unconventional ideas, explanations of error. Yet, the average intelligent students are motivated by the developing thinking. These significant abilities are different from the communication and presentation skills which were also subject of verification.

We recommend with above-average intelligent students to work in the Economics with the help of progressive teaching methods, problem solving through higher levels of Bloom's taxonomy (i.e. application, analysis, synthesis, evaluation or creativity). These procedures can be achieved by using of activate teaching methods. It is desirable to work with average students with the help of the combination of traditional and activate methods. To increase their interest in the Economics is required to exposition of curriculum with practical examples and use Bloom's taxonomy rather to the level of application.

Our research will also tend to elaborate the methodology and examples for working with these groups of students. This proposal will then be experimentally verified.

\section{Acknowledgements}

This article was supported by Internal Grant Agency of University of Economics, Prague - project VŠE IGS F1/31/2015 and it is part of a project of Faculty of Finance and Accounting realized with help of institutional support VŠE IP100040.

\section{References}

Aff, J. and Fortmüller, R. (2013) Entrepreneurship education as a counter-hegemonic project, Kollektive Monographie Entrepreneurship-Erziehung im wissenschaflichen diskurs, Wien: MANZ.

Berková, K. and Králová, A. (2015) 'Analysis of Teaching Styles of Teachers of Economic Subjects, with the Emphasis on Teaching Accounting in Secondary Schools' Education in the Czech Republic' 2nd International Multidisciplinary Scientific Conference on Social Sciences and Arts SGEM 2015, Albena, pp. 37-44.

Boekaerts, M. (2004) 'Motivation to learn', International bureau of education, General Conference of UNESCO, Geneva, pp. 14-15.

Č́p, J. and Mareš, J. (2001) Psychologie pro učitele, Praha: Portál.

Dytrtová, R. and Krhutová, M. (2009) Učitel. Příprava na profesi, Praha: Grada.

Elliot, A. J. (1999) 'Approach and avoidance motivation and achievement goals', Educational Psychologist, Vol. 34, No. 3, pp. 169-189.

Ferreira, M., Cardosob, A. P. and Abrantesc, J. L. (2011) 'Motivation and Relationship of the Student with the School as Factors Involved in the Perceived Learning', Procedia - Social and Behavioral Sciences, Vol. 29, pp. 1707 - 1714. http://dx.doi. org/10.1016/j.sbspro.2011.11.416

Fontana, D. (2014) Psychologie ve školni praxi, Praha: Portál. Forman, A. K. (2002) Videňský maticový test, Praha: Testcentrum.

Gerstenberg F.X.R., Imhoff R., Banse R. and Schmitt, M. (2014) 'Discrepancies between implicit and explicit self-concepts of intelligence: Relations to modesty, narcissism, and achievement motivation', Frontiers in Psychology, Vol. 5. http://dx.doi.org/ 10.3389/fpsyg.2014.00085

Jonsson, A. C. and Beach, J. (2012) Teachers' implicit theories of intelligence: influences from different disciplines and scientific theories. European Journal of Teacher Education, Vol. 35, No. 4, pp. 387-400. http://dx.doi.org/10.1080/02619768.2012.6626 36

Kolman, L., Chýlová, H. and Selby, R. (2012) 'An Attempt on New Systematization of work Motivation Theories', Journal on Efficiency and Responsibility in Education and Science, Vol. 5, No. 2, pp. 92-98. http://dx.doi.org/10.7160/eriesj.2012.050204

Králová, A. (2009) 'Zkvalitňování práce učitelů v předmětu ekonomika na středních školách', Acta Oeconomica Pragensia, Praha, Vol. 17, No. 2, pp. 52-65.

Krejčová, L. (2013) Žáci potřebují přemýšlet. Praha: Portál.

Krejčová, K. and Berková, K. (2016) 'Abilities of Economic Subjects' Teachers and Their Impact on Students' Motivation', Proceedings of the 13th International Conference Efficiency and Responsibility in Education 2016, Prague, pp. 286-292.

Lipovská, H. and Fischer, J. (2016) 'Talented Students and Their Family Background', Proceedings of the 13th International Conference Efficiency and Responsibility in Education 2016, pp. 319-326.

Pasiar, L. et al. (2015) Osobnost' učitel'a v ekonomickom vzdelávaní, Bratislava: vydavatel'stvo EKONÓM.

Plháková, A. (2003) Učebnice obecné psychologie. Praha: Academia.

Popa, D. (2015) 'The Relationship Between Self-Regulation, Motivation and Performance at Secondary School Students', Procedia - Social and Behavioral Sciences, Vol. 191, pp. 2549 2553. http://dx.doi.org/10.1016/j.sbspro.2015.04.410.

Sternberg, R. J. (2005). 'The Theory of Successful Intelligence', Revista Interamericana de Psicología/Interamerican Journal of Psychology, Vol. 39, No. 2, pp. 189-202.

Sternberg, R. J. and Williams, W. M. (2010) Educational Psychology, Upper Saddle River: Merril.

Tetteh, G. A. and Sarpong, F. A. (2015) 'Infuence of type of assessment and stress on the learning outcome', Journal of International Education in Business. Vol. 8, No. 2, pp. 125-144. Tohidi, H. and Jabbari, H. M. (2012) 'The effects of motivation in education', Procedia - Social and Behavioral Sciences, Vol. 31, pp. 820-824. http://dx.doi.org/10.1016/j.sbspro.2011.12.148 Vostrá Vydrová, H., Jindrová, A. and Dömeová, L. (2012) 'Evaluation of Results in Chosen Subjects and analysis of the Motivation of Distance Student', Journal on Efficiency and Responsibility in Education and Science, Vol. 5, No. 1, pp. 3645. http://dx.doi.org/10.7160/eriesj.2012.050104

Windham, D. M. (1988) 'Effectiveness Indicators in the Economic Analysis of Educational Activities', International Journal of Educational Research, Vol. 12, No. 6, pp. 575-665.

Zoller, U. (2015) 'Research-Based Transformative Science/ STEM/STES/STESEP Education for "Sustainability Thinking": From Teaching to "Know" to Learning to "Think", Sustainability. Vol. 7, No. 4, pp. 4474-4491.

Žitný, P. and Halama, P. (2012) 'Validity of cognitive ability tests - comparison of computerized adaptive testing with paper and pencil and computer-based forms of administrations', Studia Psychologica, Vol. 54, No. 3, pp. 181-194. 